\author{
Urszula Świderska-Włodarczyk \\ (University of Zielona Góra, Poland) \\ https://orcid.org/0000-0001-6419-0059 \\ E-mail: u.swiderska-wlodarczyk@ih.uz.zgora.pl
}

\title{
Old Polish Military Education in the Context of Nobility Axiology. Jan Ryś, Żołnierska paideia. Wychowanie i szkolenie wojskowe w Polsce XVI-XVII wieku, Wydawnictwo Naukowe Akademii Ignatianum w Krakowie, Kraków 2019, pp. 752
}

Staropolska edukacja wojskowa w kontekście szlacheckiej aksjologii. Jan Ryś, Żołnierska paideia. Wychowanie i szkolenie wojskowe w Polsce XVI-XVII wieku, Wydawnictwo Naukowe Akademii Ignatianum w Krakowie, Kraków 2019, ss. 752

\section{ABSTRACT}

The monograph by Jan Ryś deserves recognition owing to a number of reasons. It is due to the references to numerous sources, interdisciplinary narration, and therefore, the wide-ranging discourse that includes previous findings, which are complemented by the authorial novum. Thanks to the undertaken measures, the reader is granted a complementary, comprehensive publication, inclusive towards a broad research perspective, at the same time based on a consistent argumentation, which ultimately resulted in a coherent, firmly established in the atmosphere of the epoch, work. Texts of this kind, as opposed to

\begin{tabular}{|l|l|l|l|}
\hline \multicolumn{2}{|l|}{ PUBLICATION INFO } \\
\hline
\end{tabular}


those of a narrow scope of interest, are particularly valuable as they inspire scientific discussions. In the case of Żotnierska paideia one should consider an opinion, popular, though controversial as it is presented in the literature on the subject, that for the benefit of selfinterest and opportunism of nobles the soldier's morale has undergone gradual devaluation. Meanwhile, as it is proven by the sources of the period, the viewpoint does not find its confirmation in the old-Polish standards. Not only in the relatively peaceful 16th century, but also in the scarred by the constant wars 17th century, it is difficult to find even a hint of acknowledgement towards the negligence of the current norms. The deviations did occur in the heat of battle, which caused massive losses and bankruptcies. They did not lead, however, to the depreciation of the then principles, which for a long time have set a course of the noble axiology.

Key words: Polish nobility, military education and upbringing, noble axiology in the 16 th and 17 th centuries

The new monograph of Jan Ryś, mentioned in the title of my paper, was published at the end of April 2019'. Given the Author's scientific profile, this publication is by no means accidental. This is evidenced by both his affiliation (Pedagogical University of Krakow) and his significant research achievements in the history of education consisting of numerous studies and articles. The Żotnierska paideia fits well into this picture. Due to its richness of literature references, complemented by a solid knowledge of the research to date, not only does it appear as a compendium on noble military education in the 16th and 17th century Republic of Poland, but it also provides for an opportunity to discuss the issues raised in it. These discussion opportunities result from the very character of the Author's narrative, situated at many research levels. Therefore, similarly as for historians of education, it may prove of interest for specialists in the Old Polish military, as well as for researchers in social life, literature, and culture in the broadest possible understanding.

The richness of threads brought up by the discourse proposed by J. Ryś adds value to this monograph, even though not as a sole element. Other advantages include a title adequate to the content of the book, aptly determined and motivated turning points, and logical content arrangement. The latter, spanning between the extensive introduction and the Author's summary, has been divided into three main parts, entitled: Dom [Home], Świat [World] and Między ideatem a rzeczywistościa [Between the ideal and the reality]. The first part one consists of two mutually complementary chapters: Atmosfera domu rodzinnego [The atmosphere of the family home] and Wptyw środowiska wychowawczego na kształtowanie postaw prożotnierskich

1 J. Ryś, Żotnierska paideia. Wychowanie i szkolenie wojskowe w Polsce XVI-XVII wieku, Kraków 2019. 
[The influence of the educational setting on shaping pro-soldier attitudes]. They both come down to the presentation of the closest surroundings of the future war participant in the material (aristocratic manor), erudite (military literature) and social (family, neighbourhood and religious group) dimensions. The second part of the book presents an overview of the non-formalized education regarding the art of war. Despite the lack of specialized military schools in Poland, such perspectives did, in fact, exist. It could be implemented within the framework of the then educational system (Kształcenie wojskowe w polskich szkołach w XVI-XVII wieku [Military education in Polish schools in the 16th and 17th centuries]), as a result of noble educational tourism (Zagraniczna edukacja wojskowa Polaków w XVI-XVII wieku [Military education of Poles abroad in the 16th and 17th centuries]) and through practical participation in military life (Seminarium militum - obóz wojskowy jako miejsce szkolenia i wychowania żotnierskiego [The militum Seminar - a military camp as a place of military training and education]), where war art adepts gained knowledge not only about armament and combat tactics but also had the opportunity to learn the principles of military law. The last part, consisting of two chapters i.e. Wódz doskonaty [The perfect commander] and Świat żotnierskich wartości [The World of Soldier's Values], refers to noble axiology, interpreted in the context of military patterns and models, as well as anti-models, embodied by commanders and their subordinates. It all finishes with a summary in which the Author tries to find out what did the world of soldierly values in the form of the postulated educational ideal and the difficult, often different from that ideal, militarized reality had in common. On the positive side, he notes such virtues as soldier's readiness for war, their honour, courage, solidarity and devotion, while placing war cruelty, plundering, robbery and self-interest at the other end of the scale, all of them contradicting the former. This contradiction is reflected in the statement that 'it is impossible to clearly evaluate an Old Polish soldier or to create a single, clear model of a soldier'2 (p. 641). As a result, the monograph includes a complex and diverse picture of the then armed forces. It consists of both advantages and disadvantages, competence and ignorance, high moral values and the denial thereof, models and antimodels, which all, however, sum up on the positive side of the scale. At this point, one could be tempted to draw yet another final conclusion and bring it down it, stating the difference between the Greek form of paideia and its Old Polish version. As the Author emphasizes in the introduction, the aim of the former was to subordinate the individual to the general laws

2 'niemożliwa jest jednoznaczna ocena staropolskiego żołnierza, czy też stworzenie jednego klarownego ideału czy wzoru żołnierskiego'. 
(p. 10). To the contrary, the Polish variety, apart from practical and ethical soldier formation, put emphasis not only on comprehensive development but also on the uniqueness and individuality of war art adepts, expressed in individual heroism, crowned with immortal fame.

The monograph of J. Ryś has numerous advantages. Some of them have already been mentioned above. What cannot be left without a mention, is his meticulous, almost Benedictine-line, search for literature sources. His scientific argument is actually based on the references from the studied epoch, which, however, is not equivalent to leaving both earlier and contemporary studies out. As a result, the reader receives in the book a complimentary, panoramic view, taking into account a broad research perspective, and at the same time based on logical argumentation, which ultimately translated into a coherent work firmly rooted in the realities of the era. Another unquestionable value, which is worth strong emphasis, also includes the Author's departure from the typical research scheme. It consists of the common practice of discussing the bibliographical resources, state of the findings to date, which in fact, apart from the review function, does not provide added value. Moreover, in the case of issues with a long research tradition, such as Old Polish education, not only does following such practice bring nothing new to science, but it even disturbs the proportions of the argumentation, depreciating the newly-developed ideas. Let us thus leave it to the scholars of historiography, which of course does not exempt us from the obligation to familiarize ourselves with our own research field, but also does not impose pretty unproductive reduplication of previous achievements.

Interdisciplinary publications, as already stated above, as opposed to works with a narrow research spectrum, have the advantage of being capable of inspiring scientific discussion. Such a piece of research has an opportunity of not being limited to the Author's own discipline, but to go far beyond it. So, perhaps, apart from educational historians, Żotnierska paideia should also be commented on by military specialists, literature scholars or researchers of noble culture. The text under review, on the other hand, is the first opinion to be formulated from the point of view of a mentality historian. Therefore, it concerns not so much the competences acquired in the course of education, but rather the Old Polish system of values that these competencies should be accompanied by. In other words, the postulated and final effect of the Old Polish teaching should consist in an individual characterized by military professionalism, based on an unambiguously positive ethical attitude, expressed in his internal, but externally manifested integrity. This ethical attitude can be defined both in the context of military morale and noble morality, based on the 
state axiology. As such, it is connected not only with the assessment of the individual, but with this perspective, it also allows us to make references to the then vision of the world, the valuation of reality and all the related phenomena. In the first case, we can talk about and authority or a personal model, or, using the terminology preferred by educational historians, about an educational model. In the latter one, it is the relationship between this ideal and such concepts as religion, homeland, freedom, war, peace, time, family, foreigners, etc., which all define this authority.

The authority of a soldier in J. Ryś' work has been captured in two stages, in the form of an excellent commander and an exemplary subordinate. This division is fully justified. This is due to the fact that noble commanders faced higher requirements than their subordinates executing their orders. The former was expected to have appropriate knowledge, predispositions to make orders, a talent for command, authority among their subordinates, the ability to make the right decisions and the noble virtues, which included such values as piety, patriotism, loyalty, justice, prudence, loyalty, generosity, courage and honor. Such expectations were accompanied by the conviction that 'such a leader such as his army'3. Thus similar, but not identical requirements were addressed to soldiers, with the difference being that they were not intended to give orders but to execute them, they did not bear the responsibility for the whole undertaking of war, but only for the actions entrusted to them, and thus the responsibility of a subordinate was disproportionate with respect to the responsibility of the commander ${ }^{4}$. On the other hand, the internal integrity requirement applicable to all the representatives of the military hierarchy remained the same in terms of content, although for obvious reasons they were more often addressed to commanders than to privates. The same principle applied to requirements related to military professionalism and military service due to God and the Republic.

The slogan on defending faith and religion, repeated like a song refrain in the Old Polish period, is treated by the Author of Żotnierska paideia as a kind of propaganda abuse (pp. 523, 525, 532), which was in fact supposed to be the cover-up for noble interests and political opportunism. There is no doubt about the fact that such attitudes were indeed encountered. The difference was that they were rather a reason for shame than pride. By no means did they fit into the noble

3 'jaki będzie wódz, takie będzie wojsko'. A. Klinger, Stanisława Zaborowskiego program naprawy Rzeczypospolitej, Zielona Góra 1987, p. 119.

4 U. Świderska-Włodarczyk, Autorytety parlamentarne. Wzorce $i$ wzory osobowe w Rzeczypospolitej XVI i XVII wieku, Warszawa 2017, p. 128; eadem, Homo nobiles. Wzorzec szlachcica w Rzeczypospolitej XVI i XVII wieku, Warszawa 2017, pp. 156-172. 
axiology, which always prioritized the defense of the state and the Church bonding the two institutions into an inseparable unity. This is evidenced by the level of civic awareness at that time, based on the spirit of political culture ${ }^{5}$, acceptance for legalism, and the local character of the political system (monarchia mixta), which was solely created by the nobility themselves. It can be also confirmed by the relationship between this program and the leading religion i.e. Catholicism, being a kind of opposition to the orthodox Moscow, protestant Sweden and the Islamic Turkey, with which the Republic of Poland had to struggle in the 17th century. The Polish raison d'état was in harmony with the Roman Church, as the latter allowed for a double counterbalance for external enemies ${ }^{6}$. A Catholic Pole became a synonym for a noble citizen. He had a sense of responsibility for the fate of the state and the Church, which is confirmed in many sources of the epoch, starting with personal statements made in wills, silhouettes or diaries, and ending with public speeches in the Sejm and local governments. Thus, the widespread aristocratic religiousness (in spite of anti-clerical attitudes) and civic attitudes, emanating in the form of patriotism, are not so much the result of time-serving, but rather of a pro-state program in which military, parliamentary or diplomatic activities were not professionally defined ${ }^{7}$. In each case it was about service, mission or vocation ${ }^{8}$, resulting from one's origins and the associated hereditary right to dignity and honours.

The prioritization of citizenship and religiousness into aristocratic axiology standards translated into a permanent postulate of their implementation in the then existing personal role models. The latter, stemming from the achievements of antiquity and the chivalrous Middle Ages, in the first place had to take into account military values, as these were among the key ethical determinants of the era. The memory of them turned out to be extremely useful in the 17th century with its series of never-ending wars. However, modern times also brought other challenges. These were related to subjecting noble farms to market conditions, which led to the popularization of the farmer's model, changes in the political sphere, resulting in the clarification of the requirements addressed towards

5 E. Opaliński, Kultura polityczna szlachty polskiej w latach 1587-1652. System parlamentarny a społeczeństwo obywatelskie, Warszawa 1995, pp. 43, 80.

6 S. Kutrzeba, Polskie ustawy i artykuly wojskowe od XV do XVIII wieku, Kraków 1937, pp. 210, 283; J. Ronikier, Hetman Adam Sieniawski i jego regimentarze. Studium z historii mentalności szlachty polskiej, Kraków 1992, pp. 25-36.

7 K.F. Werner, Narodziny szlachty. Ksztattowanie się elit politycznych w Europie, transl. K. Antkowiak, Kęty 2015, p. 193.

8 Ł. Górnicki, Dworzanin polski, ed. R. Pollak, Wrocław 1954, p. 49. 
officials and MPs, as well as in pro-social attitudes, crucial for the success of the nobility's co-deciding about the fate of the Republic of Poland.

The standards set out by Old Polish role models applied both in the 16th and 17th centuries, and long afterward. However, many works, including the monograph by J. Ryś, stress the gradual depreciation of the applicable moral norms. As the Author cites after Tadeusz Korzon: 'The period of Dymitriadas and Moscow war initiated changes in the military model. The Christian knight, a defender of the homeland and the Church ready to make sacrifices, gives way to an adventurer looking for opportunities for enrichment and being far from the noble patriotic and religious ideals, undisciplined, rebellious and confederate ${ }^{\prime 9}$.

Criticism of the nobility, expressed by its contemporaries, is often quoted to prove this hypothesis true. Complaints on the effeminacy typical for this social stratum and departure from the ideals of the ancestors can already be observed in Jan Długosz's works. Critical voices seem to intensify in direct proportion to the passage of time. In the 16th and 17th centuries, such authorities as Andrzej Frycz Modrzewski, Piotr Skarga, Szymon Starowolski and others venture numerous critical comments. All of them unanimously pointed to numerous flaws of the then nobility. However, these were the considerations on abandoning the knightly duties in favor of the comfort of landowner's life, abandoning the concerns for the Republic in favors of jobbery, interest and anti-civic attitudes that seemed to have the largest specific gravity. Plebeian environments also did not spare their criticism. It was particularly visible in the so-called 'Sowizdrzal literature' (based on absurdity and irony), which lampooned the noble customs and morality.

However, neither of them can be treated as a credible basis for concluding about the decay and moral decline of representatives of the privileged social strata. They should be rather seen as echoes of inter-stratum conflicts popping up based on competences, as well as ideological and economic issues. They are based on disputes between the clergy and the nobility over tithes, pre-marital announcements, tax burdens, and the judiciary, as well as on the importance of the promoted priorities that make up the civic duty. When reading the opinions of modern-age preachers on this subject, it is hard to resist the impression that mentally they remained in the medieval reality, when war income

9 'Okres dymitriad i wojny z Moskwą zapoczątkował zmiany w dotychczasowym ideale żołnierskim. Rycerz chrześcijański, obrońca ojczyzny i Kościoła gotowy do poświęceń ustępuje miejsca awanturnikowi, szukającemu okazji do wzbogacenia, dalekiemu od szczytnych ideałów patriotycznych i religijnych, niezdyscyplinowanemu, gotowemu do buntów i konfederacji'. J. Ryś, op. cit., pp. 42-43. 
was the basis of the economy. It is known, however, that the decline of that epoch was marked by economic revaluations, resulting in shift in the source of financing towards farming implemented by noble granges. In the new situation, their owners had to transform their qualifications and become competent managers of farming enterprises, which were intended not only themselves but also for the Republic of Poland that operated thanks to taxes worked out by these farms. The clergy seemed to have failed to notice this dependence. Dramatic calls to the owners of the manor farms to abandon their homes, protect the borders and face external aggressors, as medieval knights did, kept recurring with terrifying frequency. This would have to undermine the foundations of the economy not only of the nobility itself but also of the state. It is worth noting that these calls for military activity were not justified either in the relatively calm 16th century or in the following one, marked by never-ending wars when the nobles actively participated in the struggle against foreign invaders. They were, however, an excellent tool for church propaganda against their political competitors. Moreover, this propaganda intensified together with the emancipation of the nobility who became a co-disposer of the power, at the same time growing increasingly critical of the privileges of the local clergy. Accusations stemming from bourgeois circles has a slightly different basis. Although to some extent they related to political competences, they focused mainly on the struggle for socio-economic promotion. Besides, the nobility itself was far from being a monolith. The conflicts between the less endowed gentry and the magnates, or between the orthodox Catholics and the infidels, are both well-known. In every case, propaganda is the tool for the fight, used both against the nobility and by the nobility against their adversaries. The Old Polish literature abounds in depreciating opinions about the clergy, bourgeoisie, and peasants, which is, however, not equivalent to the deteriorating moral condition of the representatives of these social classes.

The conclusion thus is that the equality sign cannot be put between propaganda criticism, typical for a given epoch, and the actual state of affairs. In the same way, reprehensible opinions about the present and the idealization of the past centuries that recurred at all times, cannot be taken at their face value ${ }^{10}$. Such idealization, already observed in antiquity, boiled down to the promotion of the myth of the golden age by such great artists as Hesiod, Plato, Ovid, Horace, and to juxtaposing it with the iron

10 U. Świderska-Włodarczyk, Mentalność szlachty polskiej XV i XVI wieku, Poznań 2003, pp. 100-114. 
or lead of the contemporary ${ }^{11}$. It was later extensively exploited by the Church fathers, chroniclers, reformers, preachers, publicists and writers. According to Jan Długosz, it was the reign of the legendary Lech which was the Golden Age ${ }^{12}$, for Stanisław Orzechowski the period of happiness ended with the death of Sigismund I the $\mathrm{Old}^{13}$, and according to Aleksander M. Fredro, the Poles were best off in the interregnum period and during the rules of the first election kings ${ }^{14}$.

At the same time, regardless of the actual epoch, the admiration for the magnificent past was accompanied by criticism of the present. Jan from Czarnków assessed his epoch negatively, because 'there was no stability in the Kingdom of Poland, nor any justice ${ }^{\prime 15}$. Similarly did the above-mentioned Jan Długosz. In modern times, due to the proliferation of literature, such statements became even more recurring. The voices about the diseases cankering the Republic of Poland, uttered from the perspective of moralists and repairers of the world, were multiplying in great abundance ${ }^{16}$. The decline of moral standards was deplored by such writers as Jan Dantyszek and Mikołaj Rej ${ }^{17}$, speakers in the Sejm such as Rafał Leszczyński ${ }^{18}$, publicists such as Andrzej Wolan ${ }^{19}$, as well as by a variety of artists using words, brushes, and chisels for creating personifications of the state, tormented by the vices of its citizens. All evil was not institutional but lied in people and their weakness of character, caused by the alleged departure from the virtues dear to their ancestors. Due to the leading role of the nobility in state life, it attracted all the criticism of modern moralists. Back then it became a kind of fashion to grumble about the moral decay, transgressions against God and the homeland. The noble tendency to sin, the natural consequence of which was supposed to be supernatural punishment, was stigmatized: 'God has forsaken us, for we too have forsaken our God first' ${ }^{20}$. Inexcusable offenses

11 D. Śnieżko, Mit złotego wieku w literaturze polskiego renesansu. Wzory - warianty zastosowania, Warszawa 1996, pp. 8-40.

12 Jana Długosza Roczniki czyli Kroniki stawnego Królestwa Polskiego, Księga pierwsza, Księga druga, do 1038, ed. Jan Dąbrowski, transl. S. Gawęda et al., Warszawa 2009, book 1, p. 64.

13 S. Orzechowski, Policya Królestwa Polskiego, Sanok 1856, p. 6.

14 A.M. Fredro, Dzieje narodu polskiego pod Henrykiem Walezjuszem królem polskim a potem francuskim, transl. W. Syrokomla, Petersburg-Mohylew 1855, p. 4.

15 'nie było żadnej stałości w Królestwie Polskim, ani żadnej sprawiedliwości'. Kronika Jana z Czarnkowa, ed. M.D. Kowalski, transl. J. Żerbiłło, Kraków 1996, p. 111.

16 P. Skarga, Kazania sejmowe, ed. J. Tazbir, Wrocław 1995, pp. 30, 53, 73, 115, 142, 164.

17 J. Dantyszek, Pieśni, transl. A. Kamieńska, Olsztyn 1987, p. 133; Literatura staropolska. Wybór tekstów. Poezja, eds. P. Borek, R. Mazurkiewicz, Kraków 2002, p. 213.

18 Wybór mów staropolskich sejmowych i innych, comp. A. Małecki, ed. K.J. Turowski, Kraków 1860, p. 41.

19 Filozofia i myśl społeczna XVI wieku, ed. L. Szczucki, Warszawa 1978, p. 352.

20 'Naprzód nas Bóg opuścił, bośmy też my pierwszy Pana Boga opuścili'. Diariusz 
included jobbery, abandoning military service in favor of farming, the decline of the knightly spirit and indifference to public affairs. Ubiquitous discord, arbitrariness, and anarchy, exacerbated by a widespread wanton, boozing and lack of moderation were supposed to accompany the departure from patriotic values. These were the conclusive arguments raised by Marcin Bielski, Andrzej Zbylitowski, Szymon Starowolski, Andrzej Radawiecki, Wacław Kunicki, Wacław Potocki and many other critics of the Old Polish reality.

However, from today's perspective, these allegations cannot be read literally. Identical or similar ones could equally well be attributed to all times, including ours. Therefore, the hypothesis about the moral decay of nobility is ungrounded. Although in 17th century, we experienced a whole series of phenomena unfavorable for the Republic of Poland and consisting of many wars, causing substantial losses, we can in no way speak of moral decay. The abovementioned personal models, or, as J. Ryś preferred to call them, the educational ideals, had the same specific gravity as in the previous century. This leads to the conclusion that a diagnosis based on the propaganda from the epoch itself and the ubiquitous criticism of the present cannot be the ground for denial of any community.

(translated by LINGUA LAB)

\section{REFERENCES}

\section{Printed sources}

Dantyszek J., Pieśni, transl. A. Kamieńska, Olsztyn 1987.

Diariusz sejmu lubelskiego 1566 roku, ed. I. Kwiatkowska, Wrocław 1980.

Filozofia i myśl społeczna XVI wieku, ed. Lech Szczucki, Warszawa 1978.

Fredro A.M., Dzieje narodu polskiego pod Henrykiem Walezjuszem królem polskim a potem francuskim, transl. W. Syrokomla, Petersburg-Mohylew 1855.

Górnicki Ł., Dworzanin polski, ed. R. Pollak, Wrocław 1954.

Jana Dtugosza Roczniki czyli Kroniki stawnego Królestwa Polskiego, Księga pierwsza, Księga druga, do 1038, ed. J. Dąbrowski, transl. S. Gawęda et al., Warszawa 2009.

Kronika Jana z Czarnkowa, ed. Marek D. Kowalski, transl. Józef Żerbiłło, Kraków 1996.

Skarga P., Kazania sejmowe, ed. J. Tazbir, Wrocław 1995.

Wybór mów staropolskich sejmowych i innych, comp. A. Małecki, ed. K.J. Turowski, Kraków 1860.

\section{Studies}

Klinger A., Stanisława Zaborowskiego program naprawy Rzeczypospolitej, Zielona Góra 1987.

Kutrzeba S., Polskie ustawy i artykuty wojskowe od XV do XVIII wieku, Kraków 1937.

Literatura staropolska. Wybór tekstów. Poezja, eds. P. Borek, R. Mazurkiewicz, Kraków 2002.

sejmu lubelskiego 1566 roku, ed. I. Kwiatkowska, Wrocław 1980, p. 60. 
Opaliński E., Kultura polityczna szlachty polskiej w latach 1587-1652. System parlamentarny a społeczeństwo obywatelskie, Warszawa 1995.

Orzechowski S., Policya Królestwa Polskiego, Sanok 1856.

Ronikier J., Hetman Adam Sieniawski i jego regimentarze. Studium z historii mentalności szlachty polskiej 1706-1725, Kraków 1992.

Śnieżko D., Mit złotego wieku w literaturze polskiego renesansu. Wzory - warianty - zastosowania, Warszawa 1996.

Świderska-Włodarczyk U., Autorytety parlamentarne. Wzorce i wzory osobowe w Rzeczypospolitej XVI i XVII wieku, Warszawa 2017.

Świderska-Włodarczyk U., Homo nobilis. Wzorzec szlachcica w Rzeczypospolitej XVI i XVII wieku, Warszawa 2017.

Świderska-Włodarczyk U., Mentalność szlachty polskiej XV i XVI wieku, Poznań 2003.

Werner K.F., Narodziny szlachty. Ksztattowanie się elit politycznych w Europie, transl. K. Antkowiak, Kęty 2015.

\section{STRESZCZENIE}

Monografia Jana Rysia z wielu względów zasługuje na uwagę. Przesądzają o tym odniesienia do licznych źródeł, interdyscyplinarna narracja, a co za tym idzie wielowątkowy dyskurs, uwzględniający dotychczasowe ustalenia, uzupełnione o autorskie novum. Dzięki tym zabiegom do rąk czytelników trafiła publikacja komplementarna, panoramiczna, uwzględniająca szeroką perspektywę badawcza, a przy tym oparta na logicznym wywodzie, co w ostatecznym rozrachunku przełożyło się na pracę spójną treściowo i mocno osadzoną w realiach epoki. Tego rodzaju prace, w przeciwieństwie do tych o wąskim spectrum badawczym, mają tę zaletę, że inspirują do naukowej dyskusji. W przypadku Żotnierskiej paidei za kontrowersyjna, acz dość popularną w literaturze przedmiotu, należy uznać opinię o stopniowej dewaluacji morale żołnierskiego, zwłaszcza w XVII w., na rzecz szlacheckiej prywaty i koniunkturalizmu. Tymczasem, jak zaświadczają źródła z epoki, taki pogląd nie znajduje potwierdzenia w staropolskich standardach. Nie tylko w stosunkowo spokojnym XVI stuleciu, ale także w naznaczonym licznymi wojnami XVII w., trudno szukać choćby cienia akceptacji dla lekceważenia obowiązujących norm. Nie oznacza to, że w nieustannym ogniu walk skutkującym masowymi stratami i bankructwami, takie odstępstwa się nie zdarzały. Nigdy jednak nie przekładały się na obniżenie rangi obowiązujących standardów, które na mocy długiego trwania długo jeszcze wyznaczały azymut szlacheckiej aksjologii.

Słowa kluczowe: polska szlachta, wychowanie i edukacja wojskowa, szlachecka aksjologia w XVI i XVII wieku

\section{ABOUT THE AUTHOR}

Urszula Świderska-Włodarczyk - PhD with 'habilitation', Professor of University of Zielona Góra, an employee of the History Institute and head of the Medieval History Department. Her research interests are focused on knightly and noble culture, with particular emphasis on such manifestations as consciousness, identity, mentality, norms of conduct and patterns and personal models in Poland at the turn of the Middle Ages and in modern times. These issues have been covered in many of her articles and books. 